\title{
Engineering-Scale Vitrification of Commercial High-Level \\ Waste
}

W. F. Bonner

W. J. Bjorklund

M. S. Hanson

D. E. Knowlton

April 1980

Prepared for the U.S. Department of Energy under Contract DE-ACO6-76RLO 1830

Pacific Northwest Laboratory Operated for the U.S. Department of Energy by Battelle Memorial Institute 
NOTICE

This report was prepared as an account of work sponsored by the United States Government. Neir her the United States nor the Department of Energy, nor any of their employees, nor any of their contractors, subcontractors, or their employees, makes any warranty. express or implied, or assumes any legal liability or responsibility for the accuracy, completeness or usefulness of any information, apparatus, product or process disclosed, or represents that its use would not infringe privately owned rights

The views, opinions and conclusions contained in this report are those of the contractor and do not necessarily represent those of the United States Government or the United States Department of Energy.

\author{
PACIFIC NORTHWEST LABORATORY \\ operated by \\ BATTELLE \\ for the \\ UNITED STATES DEPARTMENT OF ENERGY \\ Under Contract DE-AC06-76RLO 1830
}
Printed in the United States of America
Available from
National Technical Information Service
United States Department of Commerce
5285 Port Royal Road
Springfield, Virginia 22151

Price: Printed Copy

*: Microfiche $\$ 3.00$

NTIS

*Pages Selling Price

\begin{tabular}{|c|c|}
\hline $001-025$ & $\$ 4.00$ \\
\hline $026-050$ & $\$ 4.50$ \\
\hline 057.075 & $\$ 5.25$ \\
\hline $076-706$ & $\$ 6.00$ \\
\hline $101-125$ & $\$ 6.50$ \\
\hline $126-150$ & $\$ 7.25$ \\
\hline $157-175$ & $\$ 8.00$ \\
\hline $176-200$ & $\$ 9.00$ \\
\hline $201-225$ & $\$ 9.25$ \\
\hline $226-250$ & $\$ 9.50$ \\
\hline $251-275$ & 870.75 \\
\hline $40 ! n$ & (n) \\
\hline
\end{tabular}




\section{DISCLAIMER}

This report was prepared as an account of work sponsored by an agency of the United States Government. Neither the United States Government nor any agency Thereof, nor any of their employees, makes any warranty, express or implied, or assumes any legal liability or responsibility for the accuracy, completeness, or usefulness of any information, apparatus, product, or process disclosed, or represents that its use would not infringe privately owned rights. Reference herein to any specific commercial product, process, or service by trade name, trademark, manufacturer, or otherwise does not necessarily constitute or imply its endorsement, recommendation, or favoring by the United States Government or any agency thereof. The views and opinions of authors expressed herein do not necessarily state or reflect those of the United States Government or any agency thereof. 


\section{DISCLAIMER}

Portions of this document may be illegible in electronic image products. Images are produced from the best available original document. 
ENGINEERING-SCALE VITRIFICATION OF COMMERCIAL HIGH-LEVEL WASTE
W. F. Bonner
W. J. Bjork lund
M. S. Hanson
D. E. Knowlton

Apri1 1980

Prepared for

the U.S. Department of Energy

under Contract DE-ACO6-76RLO 1830

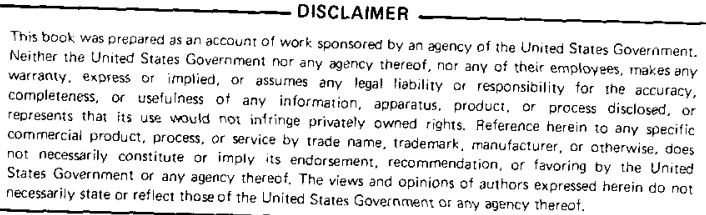

Pacific Northwest Laboratory

Richland, Washington 99352 


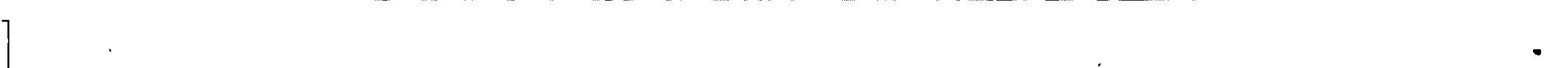


CONTENTS

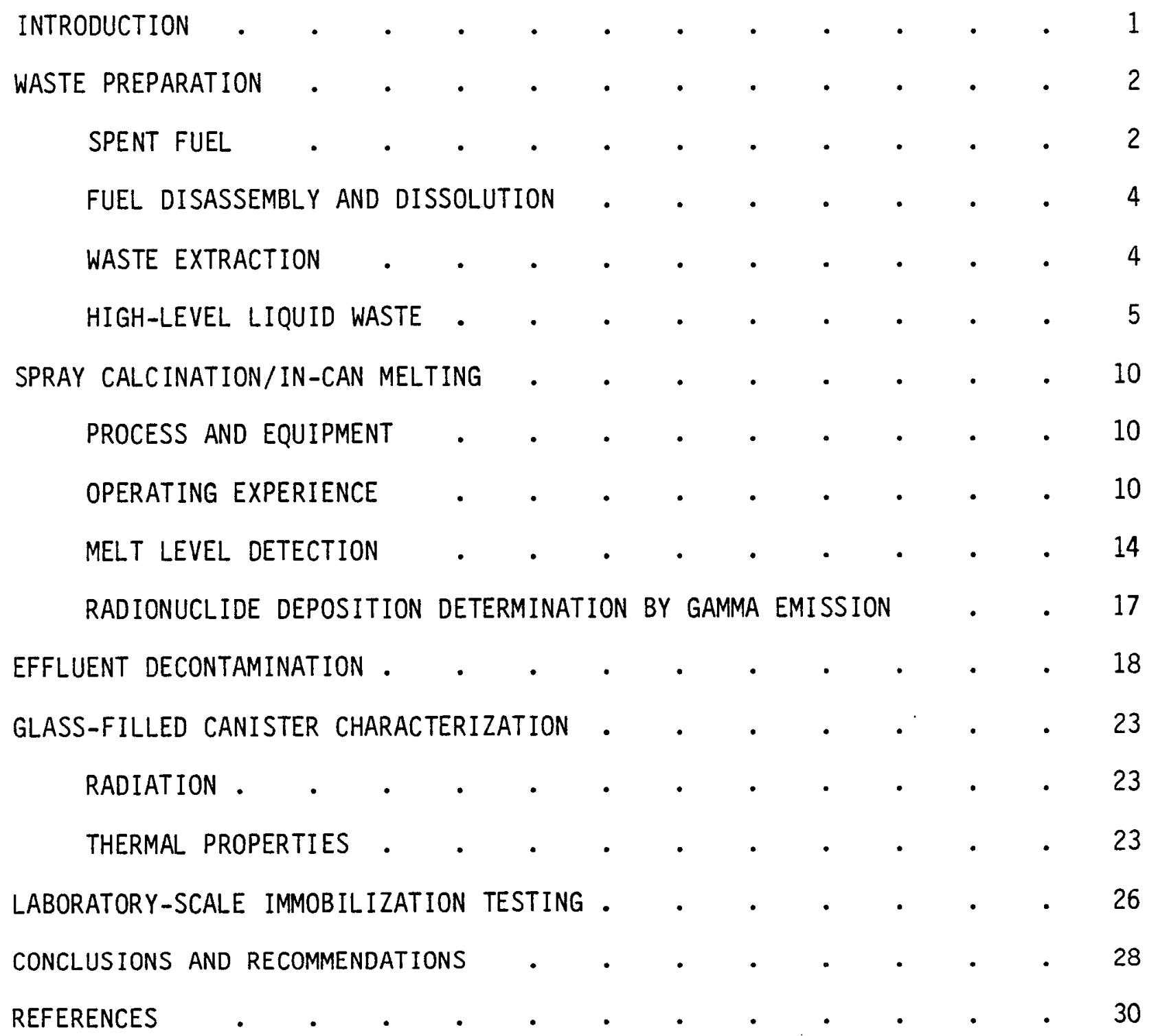

ii i 


\section{FIGURES}

1 PNL Radiochemical Engineering Cells.$\quad$. $\quad . \quad$. $\quad . \quad$. 3

2 In-Cell Spray Calciner/In-Can Melter . . . . . . . 11

3 In-Can Melter Level Detection System . . • . . . 15

4 Melt Level Indication by Gamma Emission . . . . . . 16

5 Effluent Treatment System $. \quad . \quad . \quad . \quad . \quad . \quad . \quad$. 19

6 Garma Emission Scan of Canister 1 . . . . . . . 24

7 Temperatures While Hanging in Air--Canister 1 . . . 25

8 Laboratory-Scale Immobilization Equipment . . . . 27

\section{$\underline{\text { TABLES }}$}

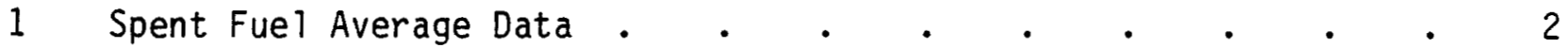

2 Calculated Waste Constituents for Run 1. . . . . . . 7

3 Calculated Waste Constituents for Run 1 . . . . . . 8

4 Inert Chemicals Added to $\mathrm{HLW}$. $\quad . \quad$. $\quad . \quad$. $\quad . \quad$. 9

5 High-Level Waste and Processing Data . . . . . . 13

6 Radionuclide Content of Process Off-Gas Particulate Matter . . 20

7. Semi-Volatile Radionuclides in Process Off-Gas . . . 20

8 Gross Activity Released to Stack . . . . . . . 21

9 Effluent Decontamination Efficiency . . . . . . 22 


\section{$\underline{\text { INTRODUCTION }}$}

The acceptance of nuclear power is currently being restrained by the need for acceptable technology to immobilize and dispose of nuclear wastes. To provide this technology, major programs have been conducted at the Pacific Northwest Laboratory (PNL), which is operated by Battelle Memorial Institute for the Department of Energy. Although detailed program objectives have changed over the years, the continual goal at PNL has been the development of waste immobilization technology. To date, technology for immobilizing commercial highlevel waste (HLW) has been extensively developed, and two major demonstration projects have been completed, the Waste Solidification Engineering Prototypes (WSEP) Program and the Nuclear Waste Vitrification Project (NWVP).

The feasibility of radioactive waste solidification was demonstrated in the WSEP program between 1966 and 1970 (McElroy et al. 1972) using simulated power-reactor waste composed of nonradioactive chemicals and HLW from spent, Hanford reactor fuel. Thirty-three engineering-scale canisters of solidified HLW were produced during the operations. In early 1979, the NWVP demonstrated the vitrification of HLW from the processing of actual commercial nuclear fuel. This program consisted of two parts, 1) waste preparation and 2) vitrification by spray calcination and in-can melting. This report presents results from the NWVP. 


\section{WASTE PREPARATION}

A pilot-scale hot cell facility plant was assembled to obtain HLW from spent, commercial nuclear reactor fuel. A conventional purex-type process was used to assure generation of waste that was representative of potential, commercial HLW.

\section{SPENT FUEL}

Spent light-water reactor (LWR) fuel from which the HLW was generated came from the storage pool at Nuclear Fuel Services' West Valley, New York plant. Six zircalloy-clad, $14 \times 14$ style bundles that had been irradiated at the Point Beach Reactor facility were used. General data on the spent fuel is given in Table 1.

The six, spent fuel assemblies were transported to PNL using a Nuclear Assurance Corporation style shipping cask. All six bundles were received and placed in a storage rack inside a hot cell before any shearing or dissolution was begun. The PNL facility for receiving, shearing and dissolving the fuel is shown in Figure 1. Fuel receiving and shearing for NWVP is discussed by Siemens (Siemens, Berger and Carter 1979).

\section{TABLE 1. Spent Fuel Average Data}

\begin{tabular}{|c|c|c|}
\hline Parameter & Bundles 1 to 3 & Bundles 4 to 6 \\
\hline Reactor & Point Beach & Point Beach \\
\hline Fuel type & LWR & LWR \\
\hline Configuration & $14 \times 14$ (179 fuel rods) & $14 \times 14$ (179 fuel rods) \\
\hline Initial enrichment & $2.27 w t \% 235 U$ & $3.04 w t \%{ }^{235} U$ \\
\hline Final enrichment & $0.85 w t \%{ }^{235} U$ & $0.94 w t \%{ }^{235} U$ \\
\hline Discharge date & Oct. 10,1972 & Apr. 10,1974 \\
\hline Burnup & $20,500 \mathrm{MWd} / \mathrm{tU}$ & $29,228 \mathrm{MWd} / \mathrm{tU}$ \\
\hline Average power & $29 \mathrm{MW}$ & $30 \mathrm{MW}$ \\
\hline Waste extraction & Dec. 1978 to Jan. 1979 & Feb. to Mar. 1979 \\
\hline
\end{tabular}




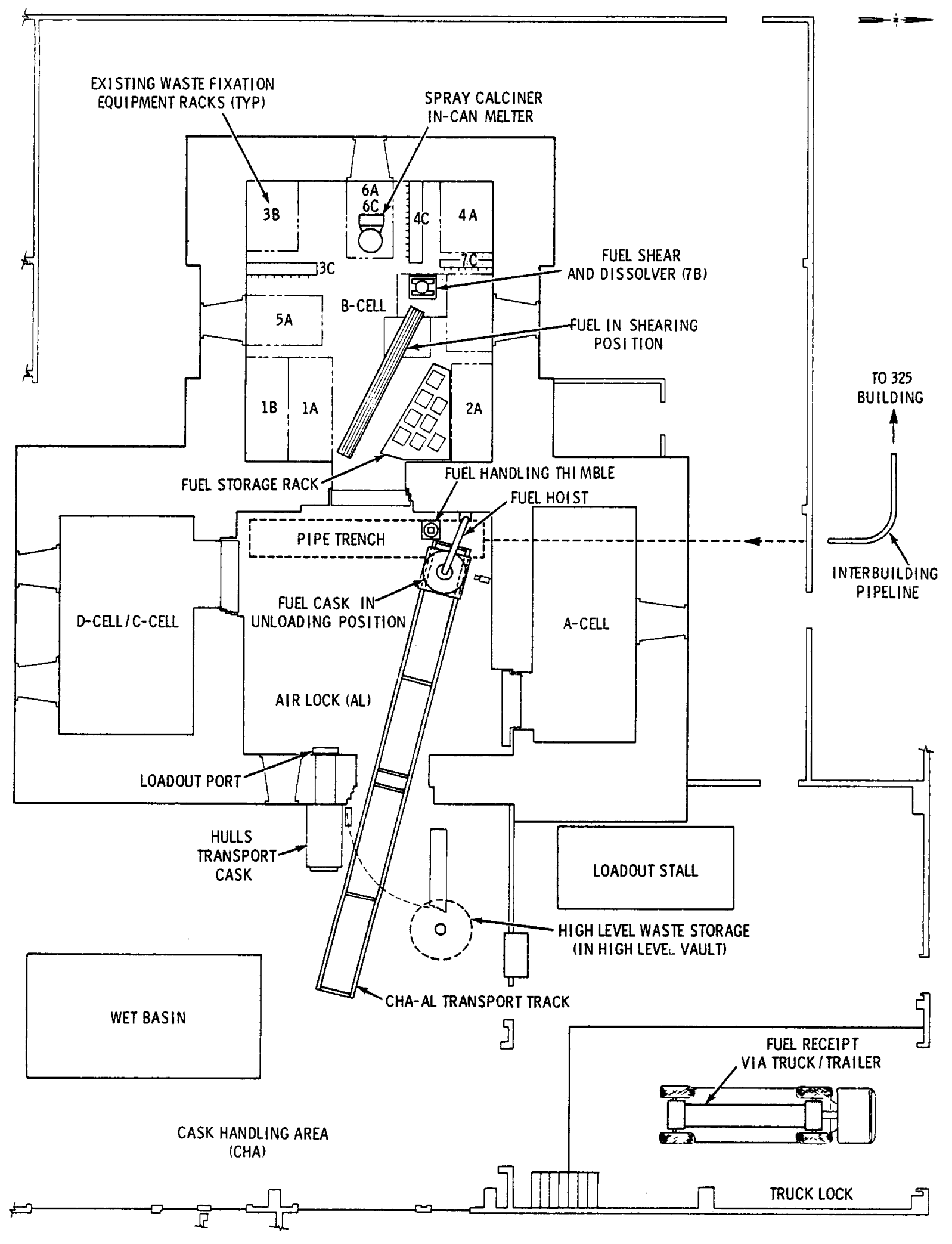

FIGURE 1. PNL Radiochemical Engineering Cells (324 Building) 


\section{FUEL DISASSEMBLY AND DISSOLUTION}

As feed for the dissolver was needed, a fuel assembly was placed on a disassembly table. The top nozzle plate was removed first by severing, with an inside tubing cutter, each of the 17 control rods and instrument tubes. The 179 zircalloy fuel rods, that-are not attached to the fuel bundle assembly heads at either end were then pulled from the assembly and were fed into a multiple tube puller with a master-slave manipulator. The fuel rods were fed into a hydraulic shear. Sheared pieces fell into the fuel dissolver. The three low-burnup fuel assemblies were disassembled and sheared first.

During a normal batch operation, 40 to 42 rods representing $86.4 \mathrm{~kg}$ of $U$ were sheared and dissolved. Twenty-six separate dissolver batches were required to process the six LWR fuel assemblies. The dissolver solution was transferred to a holding tank through a 100-u-pore, sintered stainless steel filter. Two filters were used for the 26 batches to collect dissolver solution solids for possible future characterization. The leached, spent fuel hulls were dried in a furnace and were then packaged in 5-ga1., carbon stee1, crimptop buckets. The buckets were placed in a shielded shipping cask and were shipped to retrievable storage operated by Rockwell Hanford Company.

\section{WASTE EXTRACTION}

A Purex-type solvent extraction system for the first co-decontamination cycle was selected for NWVP. In th is system, the aqueous waste stream from the extraction column contains essentially all the fission products, solids and other non-extractable impurities present in the dissolver solution. This stream becomes the HLW from the reprocessing system. For NWVP, the solvent extraction system consisted of an extraction column along with a strip column and two organic wash columns. The dissolver solution was fed to the solvent extraction system based on a flowsheet rate of $50 \mathrm{~kg} \mathrm{U} / \mathrm{d}$.

The equipment in the solvent extraction system operated quite well with only one major problem during the three months of operation. During the first three weeks of operation, including the hot startup, the equipment operated with no apparent difficulty. Thereafter, an overflow line intermittently 
plugged, which restricted the flow rate and required cleanout. Time spent on this problem delayed completion of the project by three to four weeks and reduced on-7ine efficiency from $90 \%$ before the plugging started to $62 \%$ for the overall project. Since that was the only significant problem encountered in the operation of the new facility, the overall performance was considered quite satisfactory.

The waste stream from the solvent extraction system was prepared for the ion-exchange partitioning system by concentrating the solution to $7.5 \mathrm{M} \mathrm{HNO}_{3}$. The anion ion-exchange system consisted of two separate systems; the first system was installed and operated in the hot cell, while the secondary system was $\mathrm{placed}$ in a contact-operated, shielded glovebox. Each system had a primary column sized to contain $450 \mathrm{~g} P \mathrm{Pu} / \mathrm{batch}$. Each system also had a second column as a backup or tailing column. The fission product decontamination factor for the first ion-exchange system was high enough that the plutonium product could be calcined with no further purification. The uranium-bearing streams from the ion-exchange system, along with the streams from the off-gas scrubber, the solvent wash system and the calciner off-gas condenser, were collected and sampled. These solutions were then transferred via a shipping cask by the Rockwell Hanford Operations for disposal.

The plutonium nitrate product from the ion-exchange system was directly calcined to an oxide in a continuous-fed screw calciner. This work is disussed by Bryan (Bryan, Bjorklund and Kuhn 1979). The plutonium oxide product from the calciner was cooled, weighed and then stored. Batches of approximately $2.5 \mathrm{~kg}$ were homogenized in a V-blender, sampled, reweighed and then stored.

\section{HIGH-LEVEL LIQUID WASTE}

Different wastes were used for each of the two NWVP vitrification runs. The low burnup fuel was used for Run 1. Run 2 consumed waste from the high burnup fuel and also utilized tank heels from Run 1. The reprocessing of spent fuel equivalent to $1024 \mathrm{~kg}$ of original $U$ for the first NWVP vitrification run produced $8370 \mathrm{~L}$ of $\mathrm{HLW}$, or about $8175 \mathrm{~L} / \mathrm{tU}$. Since it was desired to feed the spray calciner with $\mathrm{HLW}$ at $850 \mathrm{~L} / \mathrm{tU}$, a nearly 10-to-1 concentration 
was necessary. The processing scheme for concentrating the HLW is described by Wheelwright (Wheelwright et al. 1979). The second NWVP vitrification run consumed waste from processing spent fuel representing $860 \mathrm{~kg}$ of $U$ in the original fuel. Dilute HLW $(5130 \mathrm{~L})$ was concentrated to $650 \mathrm{~L}$ for calcination.

During concentration, acid stripping was necessary to prevent potential ruthenium volatility at high $\mathrm{HNO}_{3}$ concentrations. The nominal dilute waste was batch-concentrated from $1.5 \mathrm{M}$ to $4 \mathrm{M} \mathrm{HNO}_{3}$. Acid stripping was accomplished by adding strip water to control acid concentrations during continual concentration.

The calculated HLW fission product and actinide concentrations are shown in Tables 2 and 3. Inert, nonradioactive chemicals and uranium were added to the radioactive HLW to simulate the presence of intermediate-level wastes, corrosion products and degraded solvent. Inert additives, the same for both runs, are listed in Table 4. 
TABLE 2. Calculated Waste Constituents for Run 1 (Basis $1 \mathrm{tU}$ )

\begin{tabular}{|c|c|c|c|c|}
\hline Element & Grams & Moles & Oxide Formed & g Oxide \\
\hline \multicolumn{5}{|c|}{ Fission Products } \\
\hline $\mathrm{Ge}$ & 0.22 & 0.003 & $\mathrm{GeO}_{2}$ & 0.3 \\
\hline As & 0.05 & 0.0003 & $\mathrm{As}_{2} \mathrm{O}_{3}$ & 0.07 \\
\hline $\mathrm{Se}$ & 31.7 & 0.40 & $\mathrm{SeO}_{2}$ & 44.5 \\
\hline $\mathrm{Rb}$ & 203.0 & 1.19 & $\mathrm{Rb}_{2} \mathrm{O}$ & 222.0 \\
\hline Sr & 503.0 & 5.74 & sro & 594.8 \\
\hline Y & 284.0 & 1.60 & $\mathrm{Y}_{2} \mathrm{O}_{3}$ & 360.7 \\
\hline $\mathrm{Zr}$ & $2,280.0$ & 24.99 & $\mathrm{ZrO}_{2}$ & $3,079.8$ \\
\hline Mo & $2,130.0$ & 22.20 & $\mathrm{MoO}_{3}$ & $3,195.9$ \\
\hline Tc & 530.0 & 2.68 & $\mathrm{TC}_{2} \mathrm{O}_{7}$ & 829.8 \\
\hline Ru & $1,350.0$ & 13.36 & $\mathrm{RuO}_{2}$ & $1,777.8$ \\
\hline $\mathrm{Rh}$ & 288.0 & 1.40 & $\mathrm{Rh}_{2} \mathrm{O}_{3}$ & 355.2 \\
\hline$P d$ & 838.0 & 7.88 & bato & 964.0 \\
\hline $\mathrm{Ag}$ & 41.7 & 0.19 & $\mathrm{Ag}_{2} \mathrm{O}$ & 44.8 \\
\hline$c d$ & 45.3 & 0.40 & $\operatorname{cdo}$ & 51.7 \\
\hline In & 1.0 & 0.009 & Ino & 1.1 \\
\hline Sn & 31.5 & 0.27 & $\mathrm{SnO}_{2}$ & 40.0 \\
\hline Sb & 7.7 & 0.03 & $\mathrm{Sb}_{2} \mathrm{O}_{3}$ & 9.2 \\
\hline Te & 348.0 & 2.73 & $\mathrm{TeO}_{2}$ & 435.3 \\
\hline Cs & $1,530.0$ & 5.76 & $\mathrm{Cs}_{2} \mathrm{O}$ & $1,622.0$ \\
\hline $\mathrm{Ba}$ & 975.0 & 7.10 & $\mathrm{BaO}$ & $1,089.0$ \\
\hline La & 782.0 & 2.81 & $\mathrm{La}_{2} \mathrm{O}_{3}$ & 917.1 \\
\hline $\mathrm{Ce}$ & $1,520.0$ & 10.85 & $\mathrm{CeO}_{2}$ & $1,867.0$ \\
\hline $\mathrm{Pr}$ & 738.0 & 0.87 & $\mathrm{Pr}_{6} \mathrm{O}_{11}$ & 891.6 \\
\hline$N d$ & $2,520.0$ & 8.74 & $\mathrm{Nd}_{2} \mathrm{O}_{3}$ & $2,939.0$ \\
\hline$P_{m}$ & 22.1 & 0.08 & $\mathrm{Pm}_{2} \mathrm{O}_{3}$ & 25.7 \\
\hline Sm & 571.0 & 1.90 & $\mathrm{Sm}_{2} \mathrm{O}_{3}$ & 662.2 \\
\hline Eu & 95.3 & 0.31 & $\mathrm{Eu}_{2} \mathrm{O}_{3}$ & 110.4 \\
\hline Gd & 54.3 & 0.17 & $\mathrm{Gd}_{2} \mathrm{O}_{3}$ & 62.6 \\
\hline Tb & 1.2 & 0.002 & $\mathrm{~Tb}_{4} \mathrm{O}_{7}$ & 1.4 \\
\hline Dy & 0.8 & 0.002 & $\mathrm{Dy}_{2} \mathrm{O}_{3}$ & $\frac{0.9}{3}$ \\
\hline Subtotal & $17.7 \times 10^{3}$ & & & $22.20 \times 10^{3}$ \\
\hline \multicolumn{5}{|l|}{ Actinides } \\
\hline$u^{(a)}$ & $4,850.0$ & 6.79 & $\mathrm{U}_{3} \mathrm{O}_{8}$ & $5,719.0$ \\
\hline $\mathrm{Np}$ & 252.0 & 1.06 & $\mathrm{NpO}_{2}$ & 286.0 \\
\hline $\mathrm{Pu}$ & 38.4 & 0.16 & $\mathrm{PuO}_{2}$ & 43.5 \\
\hline Am & 84.3 & 0.35 & $\mathrm{AmO}_{2}$ & 95.5 \\
\hline $\mathrm{Cm}$ & 4.6 & 0.01 & $\mathrm{Cm}_{2} \mathrm{O}_{3}$ & 5.1 \\
\hline Subtotal & $5.23 \times 10^{3}$ & & & $6.15 \times 10^{3}$ \\
\hline TOTAL & $22.95 \times 10^{3}$ & & & $28.35 \times 10^{3}$ \\
\hline
\end{tabular}

(a) Addition of depleted $U$ required to achieve this value. 
TABLE 3. Calculated Waste Constituents for Run 2 (Basis 1 tU)

\begin{tabular}{|c|c|c|c|c|}
\hline Element & Grams & Moles & oxide Formed & g Oxide \\
\hline \multicolumn{5}{|c|}{ Fission Products } \\
\hline $\mathrm{Ge}$ & 0.33 & 0.005 & $\mathrm{GeO}_{2}$ & 0.5 \\
\hline As & 0.07 & 0.0005 & $\mathrm{As}_{2} \mathrm{O}_{3}$ & 0.1 \\
\hline $\mathrm{Se}$ & 4.65 & 0.06 & $\mathrm{SeO}_{2}$ & 6.5 \\
\hline $\mathrm{Rb}$ & 307.0 & 1.80 & $\mathrm{Rb}_{2} \mathrm{O}$ & 335.7 \\
\hline $\mathrm{Sr}$ & 758.0 & 8.65 & Sro & 896.4 \\
\hline Y & 422.0 & 2.37 & $Y_{2} \mathrm{O}_{3}$ & 535.9 \\
\hline $\mathrm{Zr}$ & $3,330.0$ & 36.51 & $\mathrm{ZrO}_{2}$ & $4,498.0$ \\
\hline Mo & $3,100.0$ & 32.31 & $\mathrm{MOO}_{3}$ & $4,651.0$ \\
\hline TC & 759.0 & 3.83 & $\mathrm{TC}_{2} \mathrm{O}_{7}$ & $1,188.0$ \\
\hline $\mathrm{Ru}$ & $1,920.0$ & 19.0 & $\mathrm{RuO}_{2}$ & $2,528.0$ \\
\hline $\mathrm{Rh}$ & 369.0 & 1.79 & $\mathrm{Rh}_{2} \mathrm{O}_{3}$ & 455.0 \\
\hline Pd & $1,210.0$ & 11.37 & Pado & $1,392.0$ \\
\hline $\mathrm{Ag}$ & 53.7 & 0.25 & $\mathrm{Ag}_{2} \mathrm{O}$ & 57.7 \\
\hline $\mathrm{Cd}$ & 69.1 & 0.61 & $\mathrm{CdO}$ & 78.9 \\
\hline In & 1.2 & 0.01 & Ino & 1.4 \\
\hline Sn & 44.8 & 0.38 & $\mathrm{SnO}_{2}$ & 56.9 \\
\hline Sb & 11.4 & 0.05 & $\mathrm{Sb}_{2} \mathrm{O}_{3}$ & 13.6 \\
\hline Te & 502.0 & 3.93 & $\mathrm{TeO}_{2}$ & 627.9 \\
\hline Cs & $2,240.0$ & 8.43 & $\mathrm{Cs}_{2} \mathrm{O}$ & $2,375.0$ \\
\hline $\mathrm{Ba}$ & $1,420.0$ & 10.34 & $\mathrm{BaO}$ & $1,585.0$ \\
\hline La & $1,140.0$ & 4.10 & $\mathrm{La}_{2} \mathrm{O}_{3}$ & $1,337.0$ \\
\hline $\mathrm{Ce}$ & $2,230.0$ & 15.91 & $\mathrm{CeO}_{2}$ & $2,739.0$ \\
\hline $\mathrm{Pr}$ & $1,080.0$ & 1.28 & $\operatorname{Pr}_{6}{ }^{0} 11$ & $1,305.0$ \\
\hline Nd & $3,680.0$ & 12.76 & $\mathrm{Nd}_{2} \mathrm{O}_{3}$ & $4,293.0$ \\
\hline$P_{m}$ & 37.0 & 0.13 & $\mathrm{Pm}_{2} \mathrm{O}_{3}$ & 43.0 \\
\hline $\mathrm{Sm}$ & 803.0 & 2.67 & $\mathrm{Sm}_{2} \mathrm{O}_{3}$ & 931.2 \\
\hline Eu & 150.0 & 0.49 & $\mathrm{Eu}_{2} \mathrm{O}_{3}$ & 173.7 \\
\hline Gd & 91.2 & 0.29 & $\mathrm{Gd}_{2} \mathrm{O}_{3}$ & 105.1 \\
\hline Tb & 1.58 & 0.002 & $\mathrm{~Tb}_{4} \mathrm{O}_{7}$ & 1.9 \\
\hline Dy & 0.92 & 0.003 & $\mathrm{Dy}_{2} \mathrm{O}_{3}$ & 1.9 \\
\hline Subtotal & $25.7 \times 10^{3}$ & & & $32.2 \times 10^{3}$ \\
\hline \multicolumn{5}{|l|}{ Actinides } \\
\hline$u^{(a)}$ & $4,800.0$ & 6.72 & $\mathrm{U}_{3} \mathrm{O}_{8}$ & $5,660.0$ \\
\hline$N p$ & 426.0 & 1.80 & $\mathrm{NpO}_{2}$ & 483.5 \\
\hline $\mathrm{Pu}$ & 40.6 & 0.17 & $\mathrm{PuO}_{2}$ & 46.0 \\
\hline Am & 297.0 & 1.23 & $\mathrm{AmO}_{2}$ & 336.4 \\
\hline $\mathrm{Cm}$ & 11.4 & 0.02 & $\mathrm{Cm}_{2} \mathrm{O}_{3}$ & 12.5 \\
\hline Subtotal & $5.58 \times 10^{3}$ & & & $6.54 \times 10^{3}$ \\
\hline TOTAL & $31.3 \times 10^{3}$ & & & $38.7 \times 10^{3}$ \\
\hline
\end{tabular}

(a) Addition of depleted $U$ required to achieve this value. 
TABLE 4. Inert Chemicals Added to HLW $(\mathrm{kg} / \mathrm{tU})$

\begin{tabular}{ll} 
Compound \\
\hline $\mathrm{NaNO}$ \\
$\mathrm{Fe}\left(\mathrm{NO}_{3}\right)_{3}$ & $9 \mathrm{H}_{2} \mathrm{O}$ \\
$\mathrm{Cr}\left(\mathrm{NO}_{3}\right)_{3}$ & $9 \mathrm{H}_{2} \mathrm{O}$ \\
$\mathrm{Ni}\left(\mathrm{NO}_{3}\right)_{2}$ & $6 \mathrm{H}_{2} \mathrm{O}$ \\
$\mathrm{H}_{3} \mathrm{PO}_{4}(75 \%)$
\end{tabular}

\begin{tabular}{|c|c|}
\hline Run 1 & Run 2 \\
\hline 23.67 & 34.91 \\
\hline 84.55 & 124.71 \\
\hline 3.72 & 5.49 \\
\hline 1.55 & 1.99 \\
\hline 1.52 & 2.24 \\
\hline
\end{tabular}




\section{SPRAY CALCINATION/IN-CAN MELTING}

\section{PROCESS AND EQUIPMENT}

The PNL in-cell spray calciner and in-can melter are shown schematically in Figure 2. The spray calciner is a heated, vertically mounted chamber $35.6 \mathrm{~cm}$ in dia by $197.5 \mathrm{~cm}$ high (14 in. in dia by $77.8 \mathrm{in}$. high) into which liquid waste is sprayed and dried. The calciner spray chamber walls are heated to about $750^{\circ} \mathrm{C}$ by a 3 -zone, $45-\mathrm{kW}$ resistance furnace surrounding the chamber. Compressed air atomizes the HLW feed solution as it enters the top of the spray chamber through a commerically available spray nozzle.

As atomized waste droplets fall through the chamber, heat is transferred from the walls by radiation and convection. As it drops through the chamber, the waste is concentrated, dried and oxidized to form a fine calcine product of typically less than $0.5 \%$ moisture and $1 \%$ nitrate. Buildup of solids on the chamber walls is prevented by periodic use of a wall-mounted, air-operated vibrator. Porous, sintered stainless steel filters remove solid particles from gases leaving the spray chamber. The off-gas filter unit contains sixteen 5.1-cm-dia by $91-\mathrm{cm}-$ long (2-in.-dia by $36-$ in.-long) filters with a nominal pore size of $65 \mu$. The calciner is operated at a nominal pressure of -12 to $-25 \mathrm{~cm}$ $(-5$ to -10 in.) of water.

Glass-forming material called frit is metered into the lower cone of the spray calciner at a rate proportional to the rate of calcine production. Frit falls with the calcine into the canister below the calciner, where the mixture is melted and then cooled to form a borosilicate glass. With in-can melting, vitrification is accomplished using the canister as the melting crucible. The canisters for NWVP were $20 \mathrm{~cm}$ in dia by $244 \mathrm{~cm}$ high ( $8 \mathrm{in}$. in dia by $8 \mathrm{ft}$ ta11). Details of the canister are presented by Bjorklund and Hanson (1979). The melter furnace is a 6-zone, resistance type. Each zone is $35.6 \mathrm{~cm}$ (14 in.) high and delivers $15 \mathrm{~kW}$ of power. The furnace operates at $1050^{\circ} \mathrm{C}$.

\section{OPERATING EXPERIENCE}

Both vitrification runs proceeded smoothly, including operation of the effluent cleanup system. One significant mishap occurred that affected 


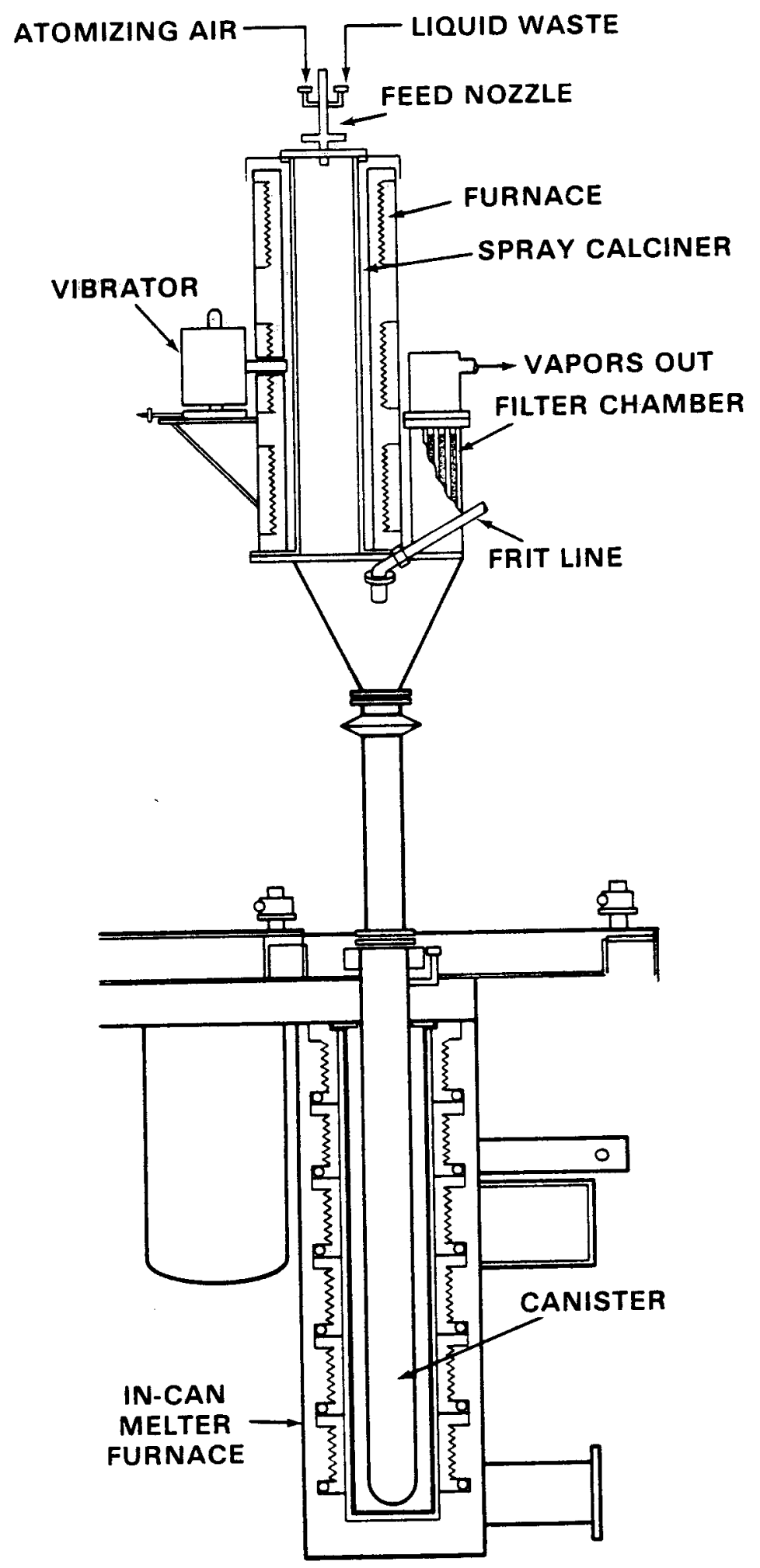

FIGURE 2. In-Cel1 Spray Calciner/In-Can Melter 
operations. This mishap can be readily avoided in the future. A weld was mistakenly omitted during the assembly of the calciner nozzle; consequently, the ceramic insert in the nozzle broke loose during Run 1. Due to an error in the feed system design, this failure was not noticed until after the run. Without the insert, little atomization of the liquid feed occurred, which resulted in a buildup of dried waste on the lower cone of the spray calciner. This explained a lower-than-expected glass volume in Canister 1. The material was remotely removed from the calciner cone before Run 2. A small amount of this material plus some frit was added to the second canister before Run 2 .

A11 other processing equipment operated well. The sintered-metal, off-gas filters removed the entrained calcine dust with little further drop in pressure. Filters were blown back every $20 \mathrm{~min}$, and the spray chamber was vibrated every 30 min. Pumps, furnaces, frit feeders and auxiliary equipment operated smoothly during both runs.

The waste-glass canisters were held at operating temperature during the entire filling operation. At the end of each run, the filled canister was cooled in the furnace with forced air unt $i 1$ the canister wall temperatures reached $550^{\circ} \mathrm{C}$; this process took about $2 \mathrm{~h}$. The canister walls were held at $550^{\circ} \mathrm{C}$ for $6 \mathrm{~h}$, and the canister was then allowed to cool naturally.

Selected data for the two vitrification runs is given in Table 5 . 
TABLE 5. High-Level Waste and Processing Data

Characteristic

Calciner Feed

Concentration, L/tU

$\mathrm{HNO}_{3}, \underline{M}$

Solids content, g oxide/L

Heat content, W/L

Activity, $\mathrm{C} i / \mathrm{L}$

Feed processed, $L$

Average feed rate, $L / h$

Run time, $h$

Average fuel burnup, MWd/tU

Onstream factor, \%

\begin{tabular}{|c|c|}
\hline \multicolumn{2}{|c|}{ Value } \\
\hline Run 1 & Run 2 \\
\hline 833 & 760 \\
\hline 4.4 & 6.6 \\
\hline 66 & 86 \\
\hline 1.12 & 2.05 \\
\hline 313 & 526 \\
\hline 806 & 430 \\
\hline 15.7 & 12.7 \\
\hline 53 & 33.6 \\
\hline 20,400 & 25,900 \\
\hline 99 & 96 \\
\hline
\end{tabular}

Glass-Filled Canister

Net glass weight, $\mathrm{kg}$

116

22.3

$145^{(a)}$

Net calcine added, $\mathrm{kg}$

93.7

37.0

Net frit added, $\mathrm{kg}$

2.8

83.7

Estimated bulk density, $\mathrm{g} / \mathrm{cm}^{3}$

Fill height, cm

137

Glass volume, $L$

41.3

$4.2: 1$

2.8

2.7

Frit-to-Calcine ratio

Glass density, $\mathrm{g} / \mathrm{cm}^{3}$

Equivalent uranium fuel, $t U$

Decay heat, (b) $w$

Activity,

(b) $\mathrm{Ci}$
0.40

380

$1.05 \times 10^{5}$
175

52.9

2.2:1

2.7

0.72

1,010

$2.64 \times 10^{5}$

(a) Includes $8.2 \mathrm{~kg}$ calcine and $16.3 \mathrm{~kg}$ frit added to the canister during spray calciner cleanout.

(b) Based on ORIGEN computer code predictions. 


\section{MELT LEVEL DETECTION}

During NWVP, intrinsic gamma emissions were monitored to determine the melt level in the in-can melter. In this technique, collimators that partially penetrate the cell wall provide view points at various canister heights, as shown in Figure 3. Gamma radiation intensity at the detector drastically increases as the melt level rises past the collimator view point. Thus, the time at which the melt level reaches the view point is known. As many view points as needed can be used. This technique is applicable to many radioactive processes needing level detection capabilities.

In preparation for demonstrating the gamma emission monitoring technique, six horizontal holes were drilled partially through the cell wall. The holes were fitted with interchangeable lead collimators having bore diameters ranging between 0.25 to $3.2 \mathrm{~mm}$. The collimators permitted the detector to "view" approximately $1 \mathrm{~cm}^{2}$ of the canister while in the melter at four vertical locations. Collimators were also placed to allow viewing of the calciner filter chamber and the calciner cone directly beneath the spray nozzle. Gamma emissions from the waste passed through equipment, miscellaneous in-cell items, the stainless steel cell liner and approximately $5 \mathrm{~cm}$ of concrete before reaching the collimator and detector. The detector, a germanium diode, was approximately $5 \mathrm{~m}$ from the radiation source.

During operations, the melt leve 1 was readily determined by monitoring ${ }^{137}$ Cs emissions. Representative data from the first test is shown in Figure 4. The sharp rise in the count rate at time $\underline{0}$ is due to calcined highlevel waste falling past the collimator line of site in the canister. The second sharp rise in the count rate at about $20 \mathrm{~h}$ represents the melt level reaching the height of the first collimator. This radiation increase by a factor of 10 in less than an hour provides accurate level indication. Similarly, other collimators higher up the canister allowed level detection at other heights.

A slight "overshoot" is apparent before the constant activity level of the final glass product is attained. This is because the bulk density of the calcine/frit mixture is lower than that of the glass, but as the calcine/frit layer melts the bulk density increases. The higher density provides internal shielding, slightly reducing radiation emissions. 


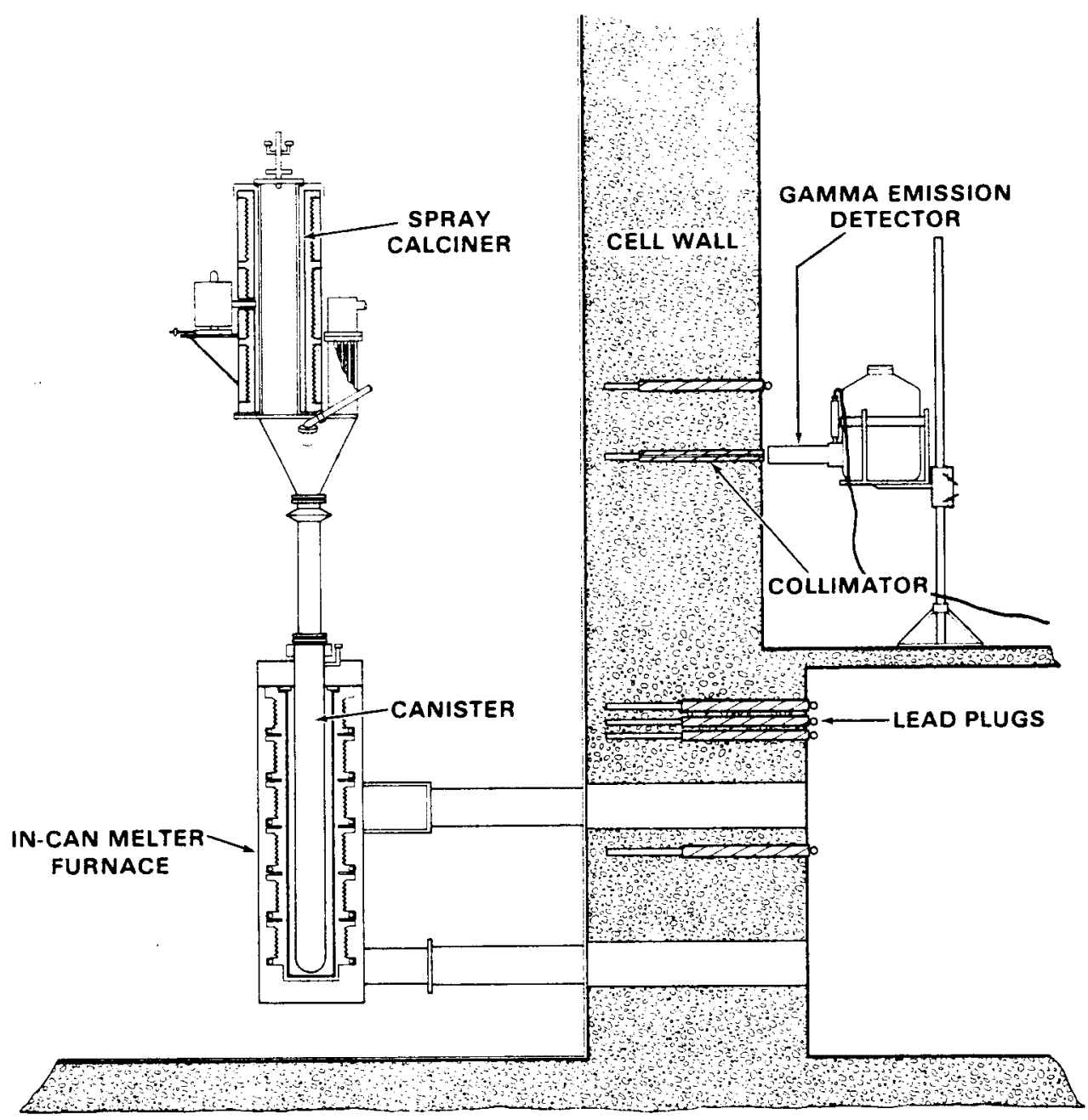

FIGURE 3. In-Can Melter Level Detection System 


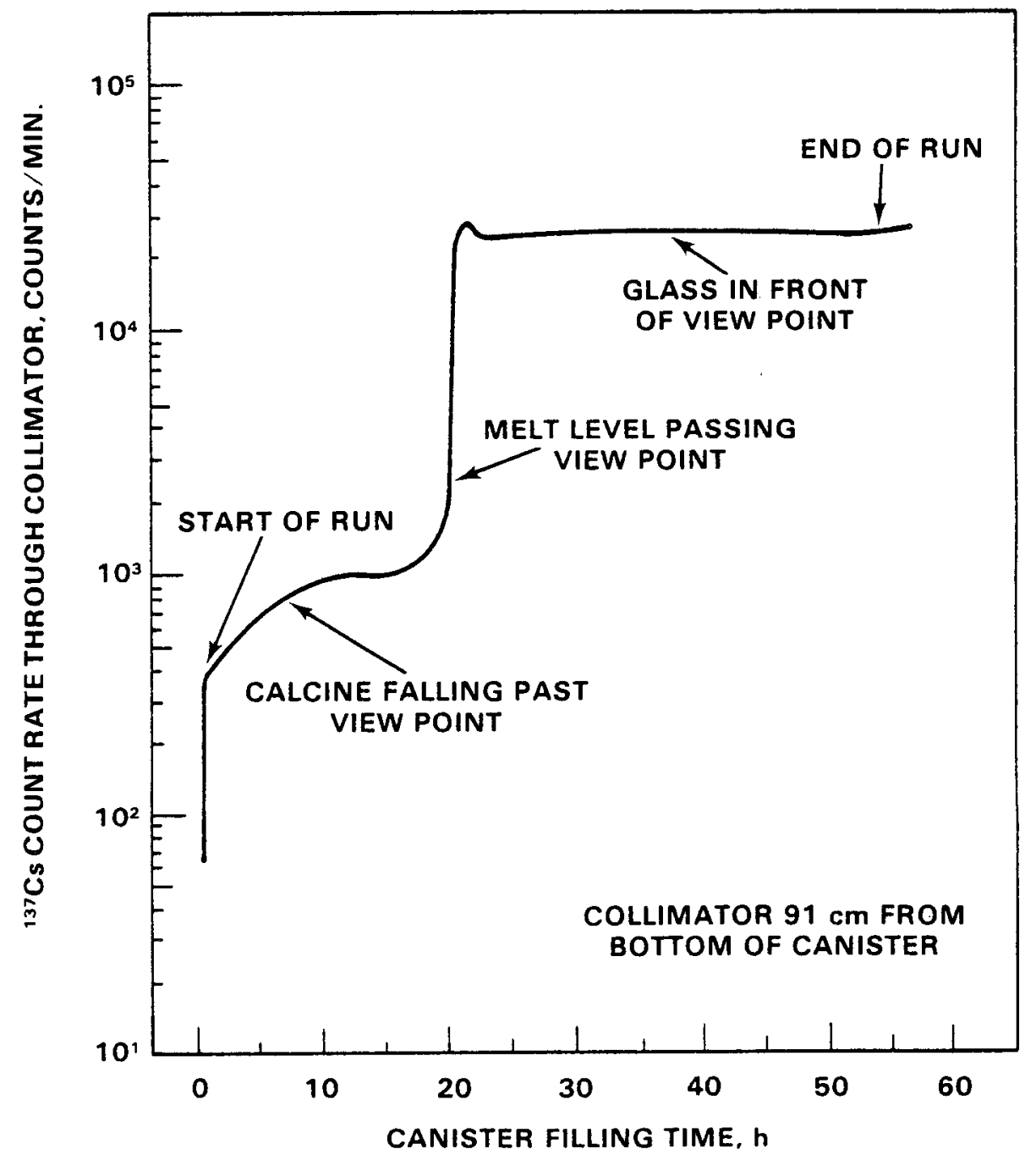

FIGURE 4. Melt Level Indication by Gamma Emission 


\section{RADIONUCLIDE DEPOSITION DETERMINATION BY GAMMA EMISSION}

Collimators viewing the calciner also provided valuable deposition data. Following the first run, very high gamma emission from the calciner cone directly below the spray nozzle indicated a buildup of dried waste in this area as a result of the previously discussed nozzle failure. Continuous monitoring at this point would have provided early warning of the buildup.

The activity level in the off-gas filter housing was monitored before, during and after the run. Since the spray calciner filters were operated at around $300^{\circ} \mathrm{C}$ during the test, selective deposition of $\mathrm{Ru}$ on the sintered stainless steel filters was anticipated. Such a deposition was observed. The concentrations of ${ }^{134} \mathrm{Cs},{ }^{137} \mathrm{Cs}$, and ${ }^{154} \mathrm{Eu}$ jumped to $30 \%$ above cell background shortly after the start of the run and then remained constant thereafter. The ${ }^{106} \mathrm{Ru}$ concentration, however, continued to increase throughout the course of the run unt il it reached a level 260\% above cell background. Operation at higher temperatures as proposed for future spray calciners should minimize, if not eliminate, Ru deposition. 


\section{EFFLUENT DECONTAMINATION}

Although determining the distribution of materials in the effluent system was not a goal of this project, a large number of samples from the effluent system were taken for analysis at a later date. A projected radiochemical balance based on the empirical values found in earlier operations of this effluent equipment is presented by Bjorklund and Hanson (1979).

Goles (Goles et al. 1979) analyzed the NWVP process off gas leaving the in-cell effluent treatment system prior to final filtration and discharge to the building stack. The effluent treatment system and the sample point used by Goles are shown in Figure 5 . The activities of particulates contained in the process off-gas are shown in Table 6 . The activities of semi-volatile species in the gas stream are given in Table 7.

Data from monitoring the building stack is also available. Gross activities released during NWVP operations via the building stack are presented in Table 8. Greater than $1.03 \times 10^{6} \mathrm{Ci}$ of beta-gamma and $4.14 \times 10^{3} \mathrm{Ci}$ of alpha materials were concentrated and solidified. Discounting the activity releases from all other sources in the building, the effluent system was shown to provide the decontamination factors ${ }^{(a)}$ given in Table 9 . During vitrification and concentration, stack releases were well within allowable limits. Future analyses of the samples taken during operation will allow evaluation of the effluent decontamination efficiency of individual treatment steps. The total system, however, has been shown to be capable of adequately decontaminating effluents from vitrification of commercial HLW.

(a) Decontamination factor is defined as the ratio of the activity of the material entering the process to that of the material exiting the process. 


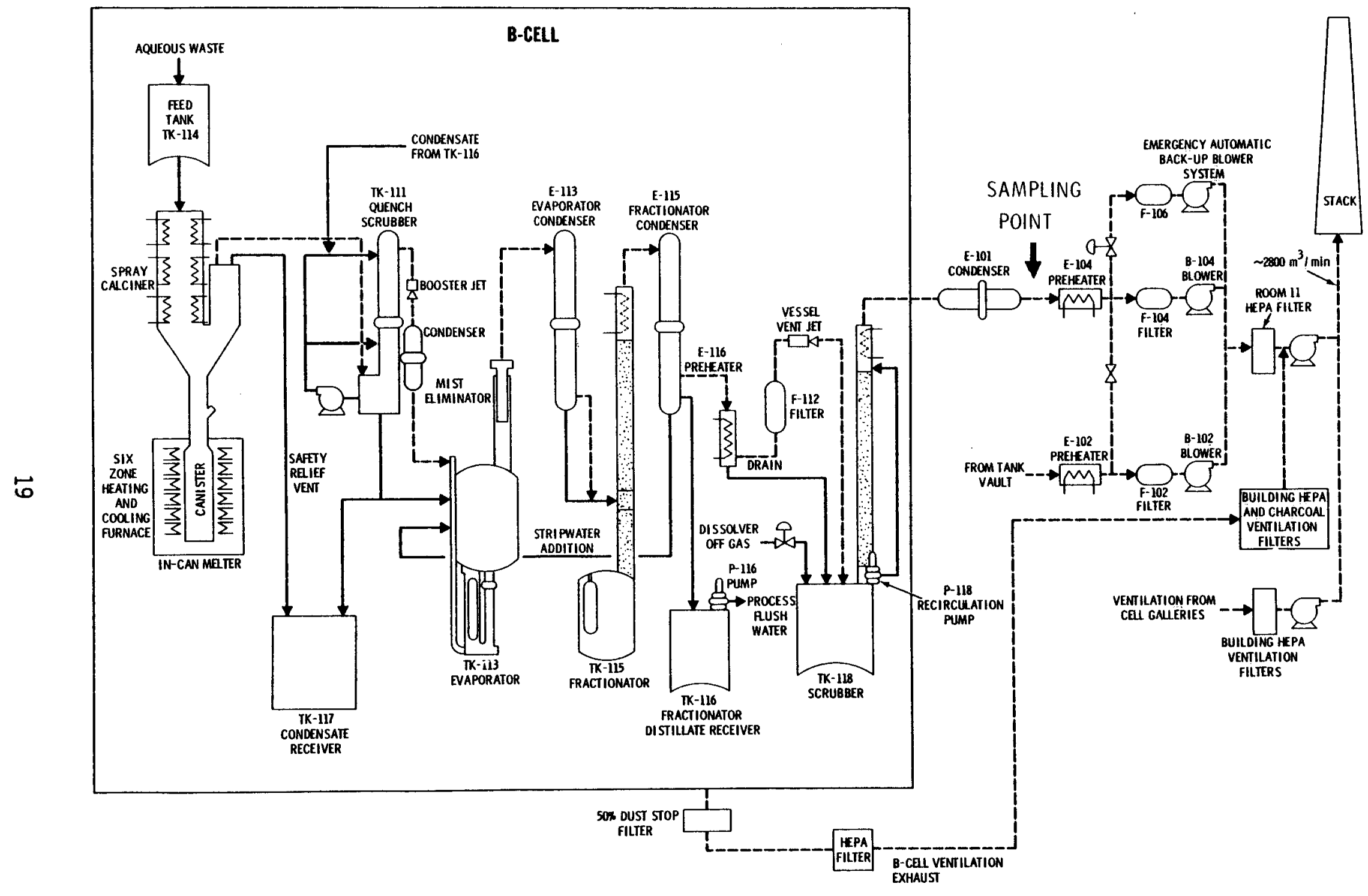

FIGURE 5. Effluent Treatment System 
TABLE 6. Radionuclide Content of Process 0ff-Gas Particulate Matter

\begin{tabular}{lc} 
Isotope & $\begin{array}{c}\text { Concentration, } \\
n C i / \mathrm{m}^{3}\end{array}$ \\
\cline { 2 - 2 }${ }^{106} \mathrm{Ru}$ & 44.0 \\
${ }^{125} \mathrm{Sb}$ & 0.52 \\
$125 \mathrm{~m}_{\mathrm{Te}}$ & 1.7 \\
${ }^{134} \mathrm{Cs}$ & 7.8 \\
${ }^{137} \mathrm{Cs}$ & 52.0 \\
${ }^{144} \mathrm{Ce}$ & 0.82 \\
${ }^{154} \mathrm{Eu}$ & 0.28 \\
$155_{\mathrm{Eu}}$ & 0.18 \\
$241_{\mathrm{Am}}$ & 0.19
\end{tabular}

TABLE 7. Semi-Volatile Radionuclides in Process off Gas

Isotope

${ }^{79} \mathrm{Se}$

${ }^{99} \mathrm{TC}$

${ }^{106} \mathrm{Ru}$

${ }^{125} \mathrm{Sb}$

${ }^{126} \mathrm{Sb}$

$125 \mathrm{~m}_{\mathrm{Te}}$

${ }^{134} \mathrm{Cs}$

${ }^{137}$ Cs

Total
Concentration

$20 \mathrm{fCi} / \mathrm{m}^{3}$

$1.6 \mathrm{pCi} / \mathrm{m}^{3}$

$200 \mathrm{nCi} / \mathrm{m}^{3}$

$50 \mathrm{nCi} / \mathrm{m}^{3}$

$3 \mathrm{nCi} / \mathrm{m}^{3}$

$0.1 \mathrm{nCi} / \mathrm{m}^{3}$

$6 \mathrm{nCi} / \mathrm{m}^{3}$

$100 \mathrm{nCi} / \mathrm{m}^{3}$

$10^{5} \frac{\mathrm{r} / \mathrm{s}}{\mathrm{m}^{3}}$ 
IABLE 8. Gross Activity Released to Stack

\begin{tabular}{|c|c|c|c|c|c|c|}
\hline \multirow[b]{2}{*}{ Operation } & \multicolumn{3}{|c|}{ Activity Released, $\mathrm{Ci}$} & \multicolumn{3}{|c|}{ Activity Concentration, $\mathrm{Ci} / \mathrm{cm}^{3}$} \\
\hline & Alpha & Beta & Gamma & Alpha & Beta & Gamma \\
\hline $\begin{array}{l}\text { Run } 1 \\
\text { HLW Concentration (a) } \\
\text { SC/ICM }(a) \text { Operations }\end{array}$ & $\begin{array}{l}1.25 \times 10^{-7} \\
4.1 \times 10^{-8}\end{array}$ & $\begin{array}{l}3.48 \times 10^{-7} \\
4.6 \times 10^{-8}\end{array}$ & $\begin{array}{l}\text { (b) } \\
\text { (b) }\end{array}$ & $\begin{array}{l}1.56 \times 10^{-15} \\
1.5 \times 10^{-15}\end{array}$ & $\begin{array}{l}4.27 \times 10^{-15} \\
1.6 \times 10^{-15}\end{array}$ & $\begin{array}{l}\text { (b) } \\
\text { (b) }\end{array}$ \\
\hline $\begin{array}{l}\text { Run } 2 \\
\text { HLW Concentration (a) } \\
\text { SC/ICM Operations }\end{array}$ & $\begin{array}{l}1.7 \times 10^{-8} \\
1.8 \times 10^{-8}\end{array}$ & $\begin{array}{l}7.8 \times 10^{-8} \\
7.3 \times 10^{-8}\end{array}$ & $\begin{array}{c}\text { (b) } \\
1.64 \times 10^{-3}\end{array}$ & $\begin{array}{l}6.4 \times 10^{-16} \\
6.5 \times 10^{-16}\end{array}$ & $\begin{array}{l}2.7 \times 10^{-15} \\
2.7 \times 10^{-16}\end{array}$ & $\begin{array}{c}\text { (b) } \\
9.5 \times 10^{-16}\end{array}$ \\
\hline
\end{tabular}

(a) During spray calciner/in-can melter (SC/ICM) operations, the spent fuel dissolution system was in operation, contributing an undetermined amount to the activities shown.

(b) Data not available. 
TABLE 9. Effluent Decontamination Efficiency

\begin{tabular}{lll}
$\frac{\text { Operation }}{\text { Run } 1}$ & \multicolumn{2}{l}{ Decontamination Factor } \\
Alpha & Beta-Gamma \\
SL concentration & $7 \times 10^{7}$ & (a) \\
SC $/$ operations & $2 \times 10^{10}$ & (a)
\end{tabular}

Run 2

HLW concentration

$1 \times 10^{11}$

SC/ICM operations

$7 \times 10^{10}$

(a)

$2 \times 10^{8}$

(a) Data not available.

(b) Spray calciner/in-can melter. 
To date, 1 imited nondestructive examination of the NWVP glass has been performed. Both canisters are available in the PNL cells for further study and final disposition.

\section{RADIATION}

Gross gamma emission, measured at a height $0.6 \mathrm{~m}$ from the bottom of Canister 1 , was observed to be $4,080 \mathrm{rad} / \mathrm{h} 1 \mathrm{~m}$ from the canister and $1,500 \mathrm{rad} / \mathrm{h}$ at a distance of $2 \mathrm{~m}$. Gamma emission from approximately $1 \mathrm{~cm}^{2}$ along the canister ax is was measured by Bryan (Bryan, Bjorklund and Kuhn 1979) during canister removal from the melting furnace. Relative concentrations of ${ }^{137} \mathrm{Cs},{ }^{154} \mathrm{Eu}$ and ${ }^{106} \mathrm{Ru}$ were measured as a function of axial position starting at the glass surface and working down to the bottom in $15 \mathrm{~cm}$ increments. The results are plotted in Figure 6 . The concentration of measured radionuclides appears to be relatively constant except for an unexplained enrichment of ${ }^{106} \mathrm{Ru}$ and ${ }^{154} \mathrm{Eu}$ and a depletion of ${ }^{137} \mathrm{Cs}$ approximately $15 \mathrm{~cm}$ below the glass surface.

\section{THERMAL PROPERTIES}

Surface and internal temperatures were measured by thermocouples on the canister exterior and in thermowe11s. Steady-state temperatures of Canister 1 hanging in air are shown in Figure 7. Maximum centerline temperatures of $130^{\circ} \mathrm{C}$ were measured near the center of the filled portion of the canister. The maximum surface temperature was $103^{\circ} \mathrm{C}$.

Heat output from $C$ anister 1 , as measured in a water bath calorimeter, was $350 \mathrm{~W}$. From the heat generation rate and centerline-to-surface temperature differences, the apparent thermal conductivity of the glass is $1 \mathrm{~W} / \mathrm{m}^{\circ} \mathrm{C}$. This compares well with laboratory data (Mendel et a1. 1972) Apparently internal cracking of the glass, which most likely occurs during cooldown, does not substantially decrease the thermal conductivity of the glass inside the canister (Wescott and Slate 1979). 


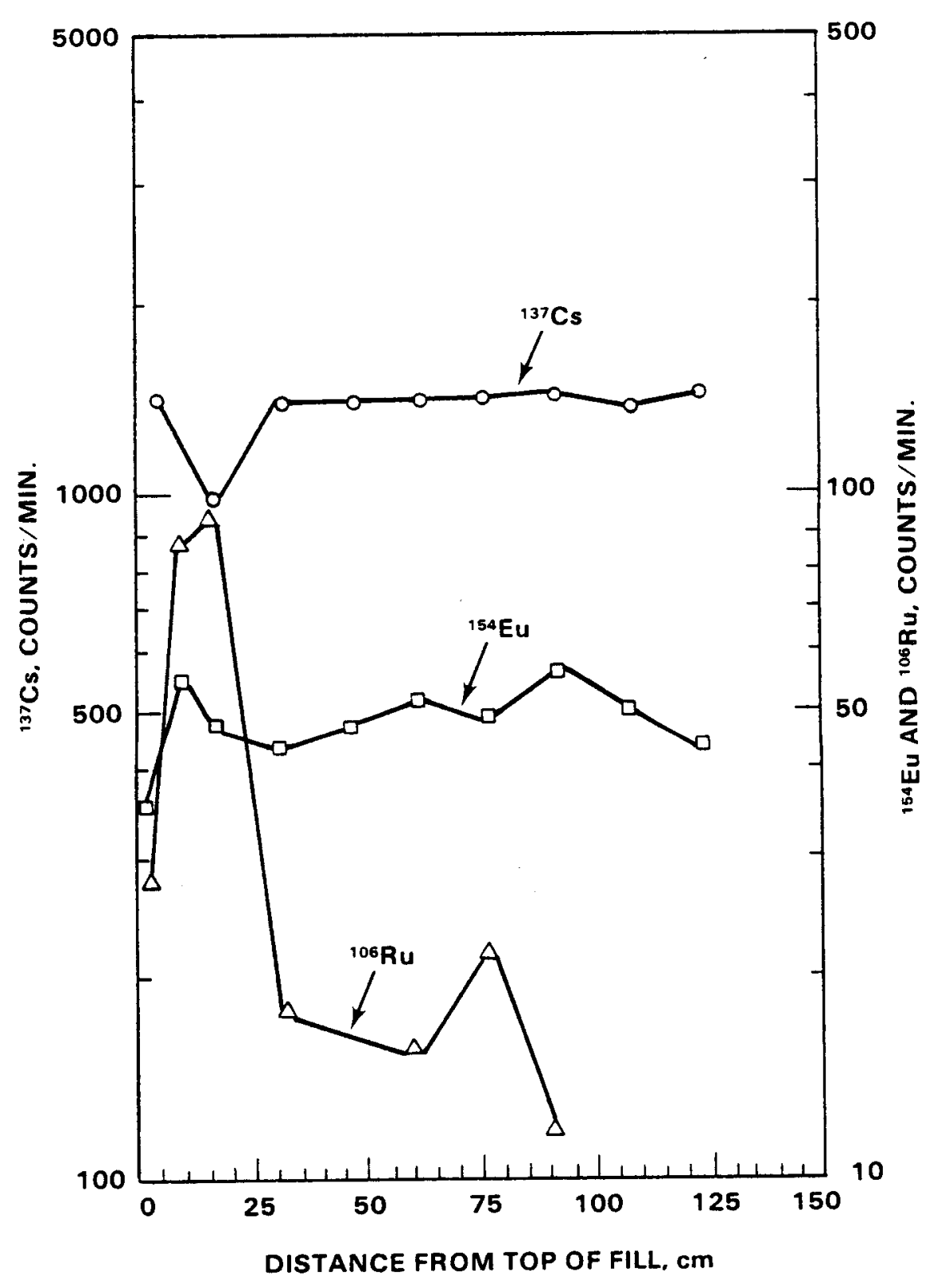

FIGURE 6. Gamma Emission Scan of Canister 1 

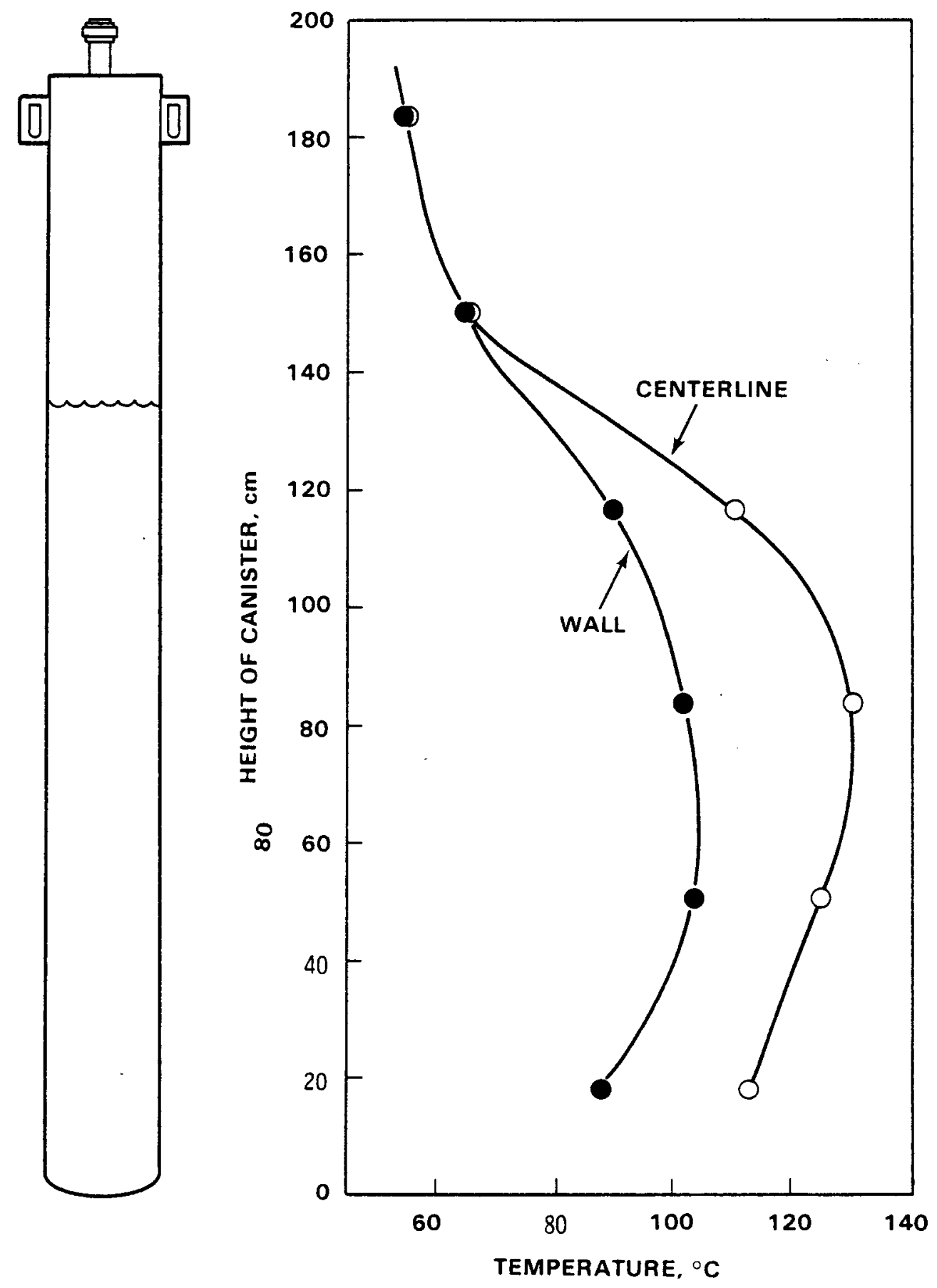

FIGURE 7. Temperatures While Hanging in Air--Canister 1 


\section{LABORATORY-SCALE IMMOBILIZATION TESTING}

A portion of the commercial HLW produced for the engineering-scale vitrification demonstration was not consumed. This valuable waste will be used in a laboratory-scale immobilization system to obtain much needed effluent processing and waste form data. A laboratory-scale system (shown in Figure 8) presently consisting of a spray calciner, an in-can melter and associated feed and off-gas systems has recently been installed in PNL hot cells. The equipment was designed in modules to readily accommodate alternative waste form processes. Because the laboratory-scale system operates at a nominal $1-L / h$ feedrate, many relatively long-term tests can be conducted with the available waste. Processing objectives are:

- evaluate effluents as a function of calciner and melter operating conditions and radioactive waste compositions

- test and improve effluent decontamination systems and evaluate a system similar to the proposed Savannah River Laboratory effluent control system

- produce solidified waste forms for evaluation

- provide a waste solidification system that can be routinely operated at minimum cost

- establish a system for radioactive testing of alternative waste forms. Plans presently call for vitrification operations to begin in mid 1980 with simulated, radioactive Savannah River Plant wastes produced using the existing HLW. Plans also include vitrification and production of alternative waste forms with commercial HLW and compositions such as simulated West Valley, New York waste. 


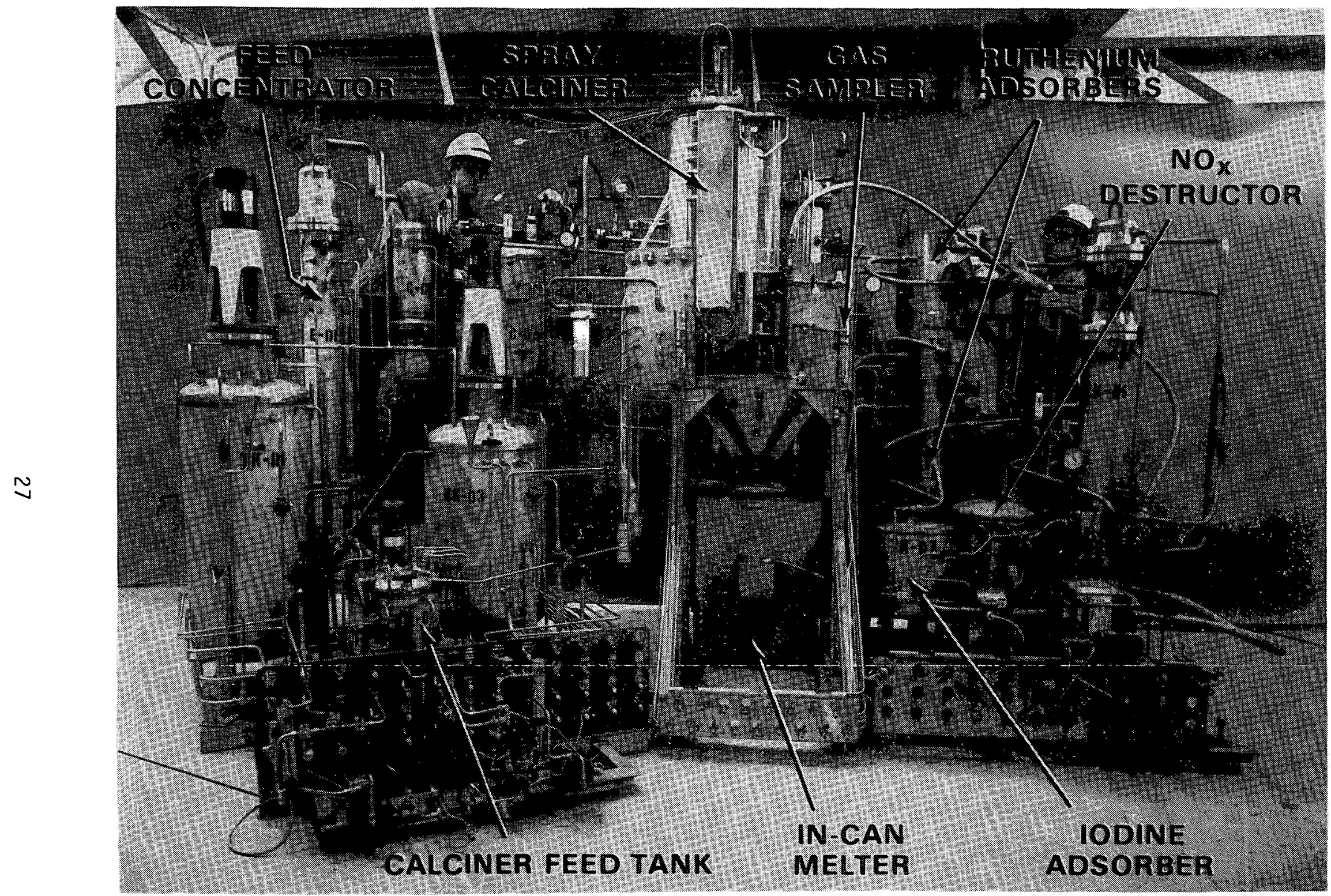

FIGURE 8. Laboratory-Scale Immobilization Equipment 


\section{CONCLUSIONS AND RECOMMENDATIONS}

The NWVP demonstration was successful not only because of completing the objective of producing two canisters of vitrified, commercial HLW, but also because a large amount of technical information was and can be obtained from the demonstration. Because of NWVP, closing of the nuclear fuel cycle has been demonstrated on an engineering scale, showing that HLW can be immobilized safely and efficiently and advancing the national goal of energy independence. Several specific conclusions can be drawn from the NWVP demonstration. They are:

- High-level waste from reprocessing of commercial nuclear reactor fuel has been and can be converted to a solid, highly inert borosilicate glass on an engineering scale. Building on this available technology, the optimization and design of an operating facility can proceed.

- Gaseous effluents from the concentration, calcination and vitrification of HLW can be adequately decontaminated to allow their release to the atmosphere within current discharge limits.

- The spray caliner/in can melter combination is a workable system for vitrifying $\mathrm{HLW}$.

- High-level waste instrinsic gamma radiation can be used to determine waste levels in vessels and to monitor bulk and/or selective radiochemical depositions on processing equipment and piping.

- The two NWVP canisters of vitrified HLW exhibit predicted properties. Due to the nature of NWVP, all obtainable data could not be gathered. Some recommendations for further study promising relatively high payoff per resources invested are:

- Effluent and liquid HLW samples obtained during NWVP operations should be analyzed and the results reported. These analyses can be used to determine radionuclide behavior during processing and the effectiveness of individual process equipment in controlling emissions. 
- The two glass-filled canisters should be characterized. Nondestructive tests, including tests of thermal properties, radiation emissions, canister condition, etc, should be performed for both canisters. One of the canisters should be core-drilled in several places and samples removed for characterization of the only engineering-scale, commercial HLW glass in the nation.

- Small-scale testing with the HLW remaining from NWVP should be conducted and plans to do so are under way. In-cell laboratory-scale equipment will allow evaluation of effluent properties, waste form characteristics and processing parameters at a relatively low cost and yet representative scale. 


\section{REFERENCES}

Bjorklund, W. J. and M. S. Hanson. 1979. Vitrification of Actual High-Level Waste from LWR Fuel. PNL-SA-7850S, Pac if ic Northwest Laboratory, Richland, WA 99352.

Bryan, G. H., W. J. Bjorklund and W. L. Kuhn. 1979. High-Level Waste Vitrification Product Characterization. PNL-SA-7807, Pacific Northwest Laboratory, Richland, WA 99352.

Goles, R. W., et al. 1979. Characterization of Gaseous Particulate Effluents from the Nuclear Waste Vitrification Project. PNL-3181, Pacific Northwest Laboratory, Richland, WA 99352.

McElroy, J. L., et al. 1972. Waste Solidification Program Summary Report, Vol. II. BNWL-1667, Pacific Northwest Laboratory, Richland, WA 99352.

Mende1, J. L., et a1. 1972. Annual Report on the Characteristics of HighLevel Waste Glass. BNWL-2252, Pacific Northwest Laboratory, Richland, WA 99352 .

Siemens, D. H., D. N. Berger and J. G. Carter. 1979. System for Receiving and Shearing LWR Spent Fuel. PNL-SA-7790-S, Pac if ic Northwest Laboratory, Richland, WA 99352.

Wescott, R. I. and S. C. Slate. 1979. Vitrification of High-Level Wastes: A Review of the Thermal Analyses for Storage Canisters. PNL-SA-7917. Pacific Northwest Laboratory, Richland, WA 99352.

Wheelwright, E. J., et al. 1979. Technical Summary-Nuclear Waste Vitrification Project. PNL-3038, Pac if ic Northwest Laboratory, Richland, WA 99352. 


\section{DISTRIBUTION}

No. of

Copies

UNITED STATES

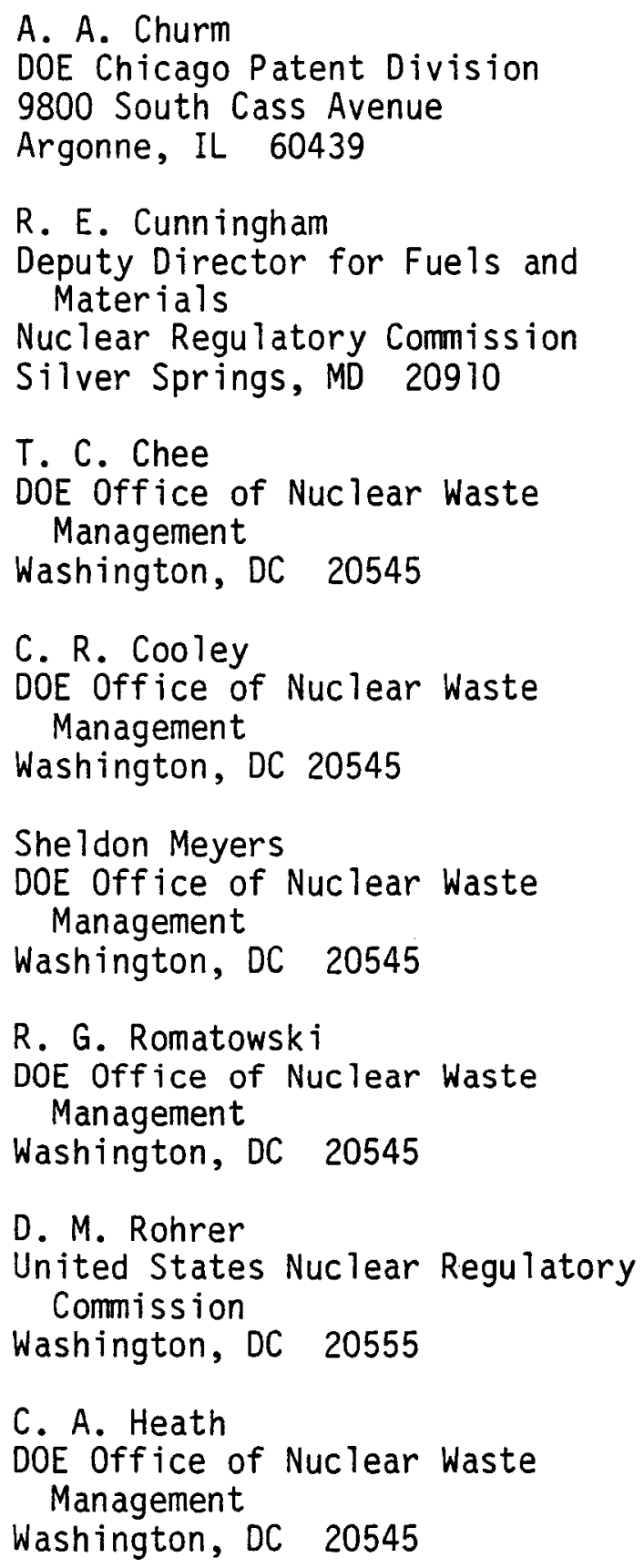

A. A. Churm

DOE Chicago Patent Division 9800 South Cass Avenue

Argonne, IL 60439

R. E. Cunningham

Deputy Director for Fuels and Materials

Nuclear Regulatory Commission

Silver Springs, MD 20910

T. C. Chee

DOE Office of Nuclear Waste Management

Washington, DC 20545

C. R. Cooley

DOE Office of Nuclear Waste Management

Washington, DC 20545

Sheldon Meyers

DOE Office of Nuclear Waste Management

Washington, DC 20545

R. G. Romatowski

DOE Office of Nuclear Waste Management

Washington, DC 20545

D. M. Rohrer

United States Nuclear Regulatory Commission

Washington, DC 20555

C. A. Heath

DOE Office of Nuclear Waste

Management

Washington, DC 20545

No. of

Copies

G. Dertel

DOE Office of Nuclear Waste

Management

Washington, DC 20545

A. F. Perge

DOE Office of Nuclear Waste

Management

Washington, DC 20545

R. D. Walton

DOE Office of Nuclear Waste

Management

Washington, DC 20545

W. E. Mott

DOE Division of Environmental

Control Technology

Washington, DC 20545

J. Neff, Program Manager

Department of Energy

Columbus Program Office

$505 \mathrm{King}$ Avenue

Columbus, $\mathrm{OH} 43201$

John Van Cleve

DOE Oak Ridge Operations Office

P.0. Box $X$

Oak Ridge, TN 37830

J. B. Whitsett

DOE Idaho Operations Office

550 2nd Street

Idaho Falls, ID 83401

E. S. Goldberg

DOE Savannah River Operations Office

P.0. Box A

Aiken, SC 29801 
No. of

Copies

27 DOE Technical Information Center

J. R. Berreth

Allied Chemical Corporation

550 2nd Street

Idaho Falls, ID 83401

Allied Chemical Corporation

(File Copy)

550 2nd Street

Idaho Falls, ID 83401

A. Williams

Allied-General Nuclear Service

P.0. Box 847

Barnwe 11, SC 29812

J. L. Jardine

Argonne National Laboratory

9700 South Cass Avenue

Argonne, IL 60439

M. M. Steindler/L. E. Trevorrow

Argonne National Laboratory

9700 South Cass Avenue

Argonne, IL 60439

Wayne Carbiener

Battelle Memorial Institute

505 King Ave.

Columbus, $\mathrm{OH} 43201$

J. Kircher

Office of Nuclear Waste Isolation

Battelle Memorial Institute

505 King Ave.

Columbus, $\mathrm{OH} 43201$

Beverly Rawles

Office of Nuclear Waste Isolation

Battelle Memorial Institute

505 King Ave.

Columbus, $\mathrm{OH} 43201$
No. of

Copies

J. W. Voss

Office of Nuclear Waste Isolation

Battelle Memorial Institute

505 King Ave.

Columbus, $\mathrm{OH} 43201$

Brookhaven National Laboratory

Reference Section

Information Division

Upton, NY 11973

J. L. Cranda 11

E. I. duPont DeNemours and Company Savannah River Laboratory

Aiken, SC 29801

T. B. Hindman

E. I. duPont DeNemours and Company Savannah River Laboratory

Aiken, SC 29801

H. L. HuIl

E. I. duPont DeNemours and Company Savannah River Laboratory

Aiken, SC 29801

R. G. Garvin

E. I. duPont DeNemours and Company Savannah River Laboratory

Aiken, SC 29801

Jim Howe 1

E. I. duPont DeNemours and Company Savannah River Laboratory

Aiken, SC 29801

D. L. McIntosh

E. I. duPont DeNemours and Company Savannah River Laboratory

Aiken, SC 29801

J. A. Kelley

E. I. duPont DeNemours and Company Savannah River Laboratory

Aiken, SC 29801 
M. D. Boersma

E. I. duPont DeNemours and Company Savannah River Laboratory

Aiken, SC 29801

S. Mirshak

E. I. duPont DeNemours and Company Savannah River Laboratory Aiken, SC 29801

A. S. Jennings

E. I. duPont DeNemours and Company Savannah River Laboratory

Aiken, SC 29801

H. Henning

Electric Power Research Institute 3412 Hillview Avenue

P.0. Box 10412

Palo Alto, CA 94301

Environmental Protection Agency

Technology Assessment Division

$$
\text { (AW-559) }
$$

Office of Radiation Programs

Washington, DC 20460

\section{R. G. Barnes}

General Electric Company

175 Curtner Avenue (M/C 858)

San Jose, CA 95125

Los Alamos Scientific Laboratory (DOE)

P.0. Box 1663

Los Alamos, NM 87544

J. P. Duckworth

Plant Manager

Nuclear Fuel Services, Inc.

P.0. Box 124

West Valley, NY 14171
J. G. Cline, General Manager

NYS ERDA

Agency Building \#2

Empire State Plaza

Albany, NY 12233

Oak Ridge National Laboratory (DOE)

Central Research Library

Document Reference Section

P.0. Box X

Oak Ridge, TN 37830

E. H. Kobisk

Solid State Division

Oak Ridge National Laboratory

Oak Ridge, TN 37830

J. Braithwaite

ORG 5831

Sandia Laboratories

P.0. Box 5800

Albuquerque, NM 87185

W. Weart

Sandia Laboratories

Albuquerque, NM 87107

J. 0. B Tomeke

Union Carbide Corporation (ORNL)

Chemical Technology Division

P.0. Box Y

Oak Ridge, TN 37830

R. E. Blanco

Union Carbide Corporation (ORNL)

Chemical Technology Division

P.0. Box $Y$

Oak Ridge, TN 37830

D. E. Ferguson

Union Carbide Corporation (ORNL)

Chemical Technology Division

P.0. Box $Y$

Oak Ridge, TN 37830 
No. of

Copies

H. W. Godbee

Union Carbide Corporation (ORNL)

Chemical Technology Division

P.0. Box Y

Oak Ridge, TN 37830

FOREIGN

D. W. Clelland

United Kingdom Atomic Energy Authority

$R$ is ley, ENGLAND

E. R. Merz

Institut fur Chemische

Technologie

Kernforschungsanloge Julich

GmbH

$\overline{\mathrm{D} 517}$ Julich

Postfach 365

Federal Republic

WEST GERMANY

H. Krause

Kernforschungszentrum Kar lsruhe $\mathrm{GmbH}$ (KfK)

Postfach 3640

D7500 Kar 1 sruhe

WEST GERMANY

S. Tashiro

Japan Atomic Energy Research Institute

Environmental Safety Research Laboratory

1-1-13, Shibashi

Minatopku, Tokyo

JAPAN

2 International Atomic Energy Agency Wagramerstrasse 5

P.0. Box 100

A-1400, Vienna, AUSTRIA
No. of

Copies

B. Morr is

Atomic Energy Research

Establ ishment,

Harwe 11, Didcot,

Berks, ENGLAND

ONSITE

3 DOE Richland Operations Office

H. E. Ransom

M. W. Shupe

M. J. Zamorski

5 Rockwell Hanford Operations

L. Brown

M. J. Kupfer

G. Reep

D. D. Wodrich

File copy

Exxon Nuclear Company

S. J. Beard

Westinghouse Hanford Company

A. G. Blasewitz

72 Pacific Northwest Laboratory

S. M. Barnes

D. N. Berger

W. J. Bjorklund

H. T. Blair

W. F. Bonner (20)

D. J. Bradley

R. A. Brouns

J. L. Buelt

J. Carrol

J. G. Carter

L. A. Chick

R. D. Dierks

T. A. Golding 
No. of

Copies

M. S. Hanson

A. J. Haverfield

M. H. Henry

L. K. Holton

J. H. Jarrett

D. E. Knowlton

C. A. Knox

W. L. Kuhn

L. T. Lakey

D. E. Larson

R. P. Marshall

S. A. McCullough (3)

J. L. MCE Troy

G. B. Mellinger

J. E. Mende 1

F. A. Miller

T. A. Nelson

R. E. Nightingale

K. H. Oma

C. R. Palmer

L. L. Petkus

A. M. Platt

D. L. Prezbindowski (2)

W. A. Ross

J. M. Rusin

D. H. Siemens

S. C. Slate

C. L. Timmerman

R. T. Treat

R. E. Westerman

Technical Information (5)

Publishing Coordination YO(2) 